Оригинальная статья/Original article

УДК 658.511.2:637.14

DOI: http://doi.org/10.20914/2310-1202-2016-2-110-117

Алгоритм действия по определению и снижению рисков при

производстве молочно-растительных продуктов

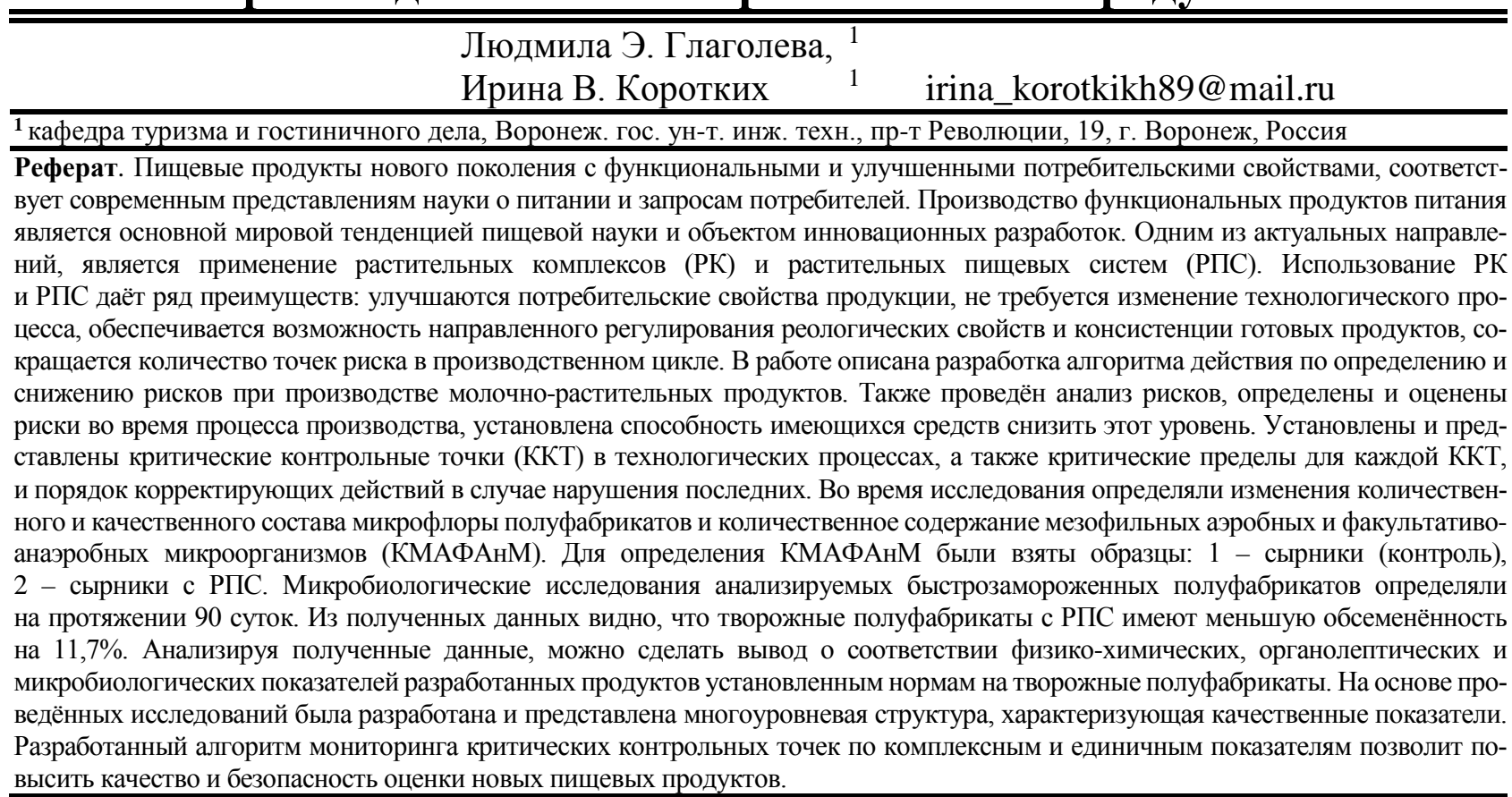

Ключевые слова: молочно-растительные продукты, растительные комплексы, растительные пищевые системы, творожные полуфабрикаты, риски, критические контрольные точки.

\title{
Algorithm of actions to identify and reduce risks in the production of milk and plant products
}

= Lyudmila E. Glagoleva, 1 .

\author{
Lyudmila E. Glagoleva, \\ Irina V. Korotkikh \\ irina_korotkikh89@mail.ru
} $\overline{1}$ department of tourism and hotel management, Voronezh state university of engineering technologies, Revolution Av., 19, Voronezh, Russia
Summary. Foods with a new generation of functional and improved consumer properties, corresponds to the modern concepts of
nutrition science and consumer needs. functional food production is a major global trend in food science and the subject of innovation.
One of the important trends is the use of plant complexes and plant food systems. Using the plant complexes (PC) and plant food
systems (PFS) provides a number of benefits: improved consumer properties of the product, do not need to change the process, it is
possible to control directional rheological properties and consistency of the finished products, reduced the number of risk points in the
production cycle. This paper describes the development of an algorithm of action to identify and mitigate risks in the production of
milk and plant products. Also conducted a risk analysis, identified and assessed the risks in the process of production, installed capacity
of available resources to reduce the level of risk. Established and submitted to the critical control points in production processes, as
well as the critical limits for each critical control points, and the procedure for corrective action in case of violations of the past. During
the study, measured changes in the quantitative and qualitative composition of microflora of semi-finished and Quantity of Mesophilic
Aerobic and Facultative Anaerobic Microorganisms (QMAFAnM). To determine QMAFAnM samples were taken: 1 - cheesecakes
(control), 2 - cheesecakes with RPS. Microbiological studies analyzed frozen-conjugated semi-finished products was determined
within 90 days. It is clear from the data that the cottage cheese with semi-finished products have a lower RPM 11.7\%. Analyzing the
data, it is possible to conclude that the physico-chemical, organoleptic and microbiological indicators of products was developed to
set standards on cheese semi-finished products. multilevel structure that characterizes the quality indicators has been developed and is
presented on the basis of the survey. The developed algorithm for monitoring critical control points on the complex and the individual
indicators will improve the quality and safety evaluations of new food products.

Keywords: milk and plant products, plant complexes, plant food systems, semi-finished cottage cheese, risks, critical control points

Для цитирования

Глаголева Л. Э., Коротких И. В. Алгоритм действия по определению и снижению рисков при производстве молочно-растительных продуктов // Вестник ВГУИТ. 2016. № 2. С. 110-117. doi:10.20914/2310-1202-2016-2-110-117
For citation

Glagoleva L. E., Korotkikh I. V. Algorithm of actions to identify and reduce risks in the production of milk and plant products. Vestnik VSUET [Proceedings of VSUET]. 2016. no.2. pp. 110-117 (in Russ.). doi:10.20914/2310-1202-2016-2-110-117 


\section{Введение}

Совершенствование ассортимента пищевой продукции определяет поиск и развитие новых направлений производства продуктов питания, которые отвечают задачам улучшения традиционных и создания инновационных технологий, более эффективному использованию сырья, повышению качества полуфабрикатов и готовой продукции, ресурсосбережению. Одним из актуальных направлений, является применение растительных комплексов (РК) и растительных пищевых систем (РПС) на их основе, обладающих спектром функционально-технологических свойств, для производства пищевых продуктов с улучшенными потребительскими и функциональными свойствами, а также с увеличенными сроками хранения. Использование РК и РПС даёт ряд преимуществ: улучшаются потребительские свойства продукции; не требуется изменение технологического процесса; обеспечивается возможность направленного регулирования реологических свойств и консистенции готовых продуктов, сокращается количество точек риска в производственном цикле.

При моделировании рецептур продуктов функционального назначения принципиальным является гарантия её безопасности и достижение заданных качественных показателей при оптимальных параметрах технологического процесса.

Одним из важнейших аспектов обеспечения безопасности пищевых продуктов является система Анализа рисков и критических контрольных точек (НАССР), предназначенная для идентификации опасных факторов (т. е. биологических, физических или химических свойств пищевой продукции, которые могут повлиять на её безопасность) и установления мер, необходимых для их контроля. Система основана на семи принципах [1].

\section{1 Материалы и методы}

Цель работы - разработка алгоритма действия по определению и снижению рисков при производстве молочно-растительных продуктов.

Для выполнения поставленной цели были выпалены следующие задачи:

- проведён анализ рисков, определены и оценены риски во время процесса производства, установлена способность имеющихся средств снизить этот уровень;

- установлены критические контрольные точки (ККТ) в технологических процессах, а также критические пределы для каждой ККТ, и порядок корректирующих действий в случае нарушения последних.

\section{2 Результаты и обсуждение}

Анализ рисков осуществлялся в 2 этапа. На первом этапе был составлен перечень всех потенциально опасных факторов (физических, химических, микробиологических). Затем проведён анализ опасных факторов в соответствии со схемами технологических процессов. Во время проведения работы были проанализированы возможные риски технологического процесса при производстве полуфабрикатов на основе творога и кисломолочных напитков.

Технологический процесс полуфабрикатов на основе творога (сырники) состоит из следующих операций: приёмка сырья, подготовка компонентов, приготовление смеси, формование, замораживание (охлаждение), упаковывание и хранение. Аппаратурно-технологическая схема производства приведена на рисунке 1 (подсистема В).

Творог, для придания ему однородной консистенции, пропускают через вальцовочную машину. Муку и сахар просеивают, необходимое количество растительныхкомплексов различного функционального назначения [2] выдерживают в растворе фермента или воды, в зависимости от функциональных свойств продукта при температуре $40{ }^{\circ} \mathrm{C}$, времени обработки 40 мин.

Все подготовленные компоненты взвешивают на весах согласно рецептуре (таблица 1). В соответствии с рецептурой, все подготовленные виды сырья отвешивают и приступают к приготовлению замеса. В месильную машину (фаршмешалку) закладывают творог, частично перемешивают, вносят предварительно перемешанные сухие компоненты, подготовленную растительную пищевую систему и тщательно перемешивают полученную смесь.

Для выработки творожных полуфабрикатов используют творог подпрессованный до влажности: 54-56\% и 58-61\% (массовая доля жира 18\%), что требует дополнительных технологических операций и расчётов. Использование РПС за счёт высокой влагоудерживающей способности позволяет сократить время технологического процесса. Перемешивание проводят до тех пор, пока смесь не достигнет однородной пластичной консистенции и равномерного распределения в ней всех составных частей. Затем проводят формование и сразу же направляют аппарат для шоковой заморозки. 


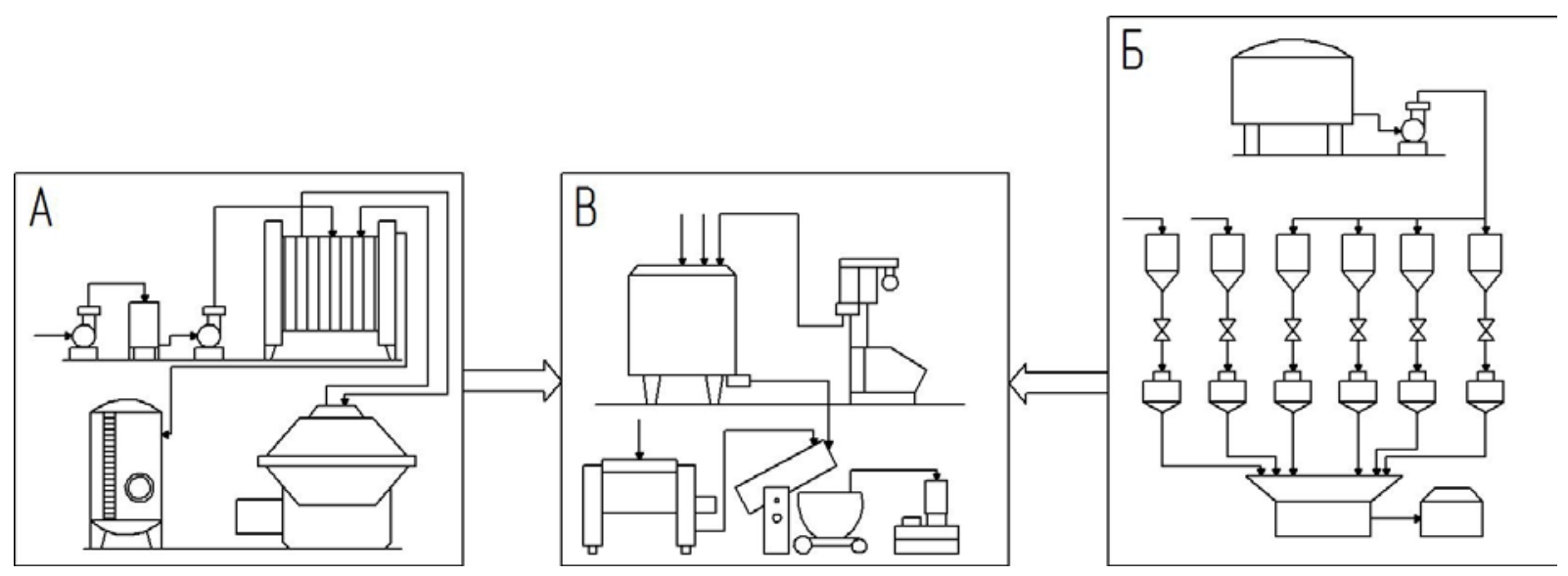

Рисунок 1. Аппаратурно-технологическая схема производства молочно-растительных продуктов: А - первичная обработка молока; Б - подсистема подготовки РК и производства РПС; В - подсистема производства полуфабрикатов на основе творога

Figure 1. Apparatus-technological scheme of milk and plant products production: A - primary processing of milk; C - subsystem preparation and production of the RK RPM; B - subsystem of semi-finished products based on cottage cheese

Таблица 1

Рецептура на сырники (в кг на 1000 г продукта без учёта потерь)

Table 1.

Cheese pancakes recipe (kg per $1000 \mathrm{~g}$ of the product without losses)

\begin{tabular}{|c|c|c|c|c|c|c|}
\hline \multirow[b]{2}{*}{$\begin{array}{l}\text { Наименование } \\
\text { сырья } \\
\text { Name of raw ma- } \\
\text { terials }\end{array}$} & \multicolumn{6}{|c|}{ Рецептура Recipe } \\
\hline & $\begin{array}{l}\text { м. д. ж. } 13,5 \% \\
\text { сладкое } \\
\text { f. m. f. } 13.5 \% \\
\text { sweet }\end{array}$ & $\begin{array}{c}\text { м. д. ж. } 7 \% \\
\text { сладкое } \\
\text { f. m. f. } 7 \% \text { sweet }\end{array}$ & $\begin{array}{c}\text { нежирное } \\
\text { сладкое } \\
\text { low-fat } \\
\text { sweet }\end{array}$ & $\begin{array}{l}\text { м. д. ж. } 15,5 \% \\
\text { солёные } \\
\text { f. m. f. } 15.5 \% \\
\text { salty }\end{array}$ & $\begin{array}{l}\text { м. д. ж. 7,5\% } \\
\text { солёные } \\
\text { f. m. f. } 7.5 \% \\
\text { salty }\end{array}$ & $\begin{array}{c}\text { Нежирное } \\
\text { солёные } \\
\text { low-fat salty }\end{array}$ \\
\hline $\begin{array}{l}\text { Творог } \\
\text { м. д. ж. 18\% } \\
\text { Cottage cheese } \\
\text { f. m. f. } 18 \%\end{array}$ & 787 & - & - & 829 & - & - \\
\hline $\begin{array}{l}\text { Творог } \\
\text { м. д. ж. 9\% } \\
\text { Cottage cheese } \\
\text { f. m. f. 9\% }\end{array}$ & & 787 & - & - & 829 & - \\
\hline $\begin{array}{l}\text { Творог } \\
\text { нежирный } \\
\text { Low-fat } \\
\text { cottage cheese }\end{array}$ & - & & 787 & - & - & 829 \\
\hline $\begin{array}{l}\text { PПC } \\
\text { PFS }\end{array}$ & 125 & 125 & 125 & 129 & 129 & 129 \\
\hline $\begin{array}{l}\text { Caxap-песок } \\
\text { Sugar }\end{array}$ & 61 & 61 & 61 & 10 & 10 & 10 \\
\hline $\begin{array}{l}\text { Мука пшеничная } \\
\text { для подсыпки } \\
\text { Wheat flour for } \\
\text { bedding }\end{array}$ & 22 & 22 & 22 & 22 & 22 & 22 \\
\hline $\begin{array}{l}\text { Соль поваренная } \\
\text { Salt }\end{array}$ & 5 & 5 & 5 & 10 & 10 & 10 \\
\hline $\begin{array}{l}\text { Итого } \\
\text { Total }\end{array}$ & 1000 & 1000 & 1000 & 1000 & 1000 & 1000 \\
\hline
\end{tabular}

* м. д. ж. - массовая доля жира

* f. m. f. - fat mass fraction 
Технология шоковой заморозки состоит в том, что температура продукта снижается на один градус за одну минуту. Продукт охлаждается до температуры от (-30) до (-40) ${ }^{\circ} \mathrm{C}$. При быстром снижении температуры воды, содержащейся в клетках пищевой системы, она не успевает

превратиться в большие кристаллы льда, разрушающие клеточные оболочки. Благодаря этому сохраняется форма, цвет и аромат. Органолептические показатели теста для сырников представлены в таблице 2. Физико-химические показатели полуфабрикатов на основе творога (сырников) представлены в таблице 3.

Микробиологические исследования являются важной составной частью технологического процесса производства пищевых продуктов. Во время исследования определяли изменения количественного и качественного состава микрофлоры полуфабрикатов и количественное содержание мезофильных аэробных и факультативо-анаэробных микроорганизмов (КМАФАнМ).

Таблица 2

Органолептические показатели сырников

Table 2

Cheese cakes organoleptic indices

\begin{tabular}{|c|c|c|c|}
\hline $\begin{array}{c}\text { Внешний вид } \\
\text { Appearance }\end{array}$ & $\begin{array}{c}\text { Консистенция } \\
\text { Consistence }\end{array}$ & $\begin{array}{c}\text { Вкус и запах } \\
\text { Taste and smell }\end{array}$ & $\begin{array}{c}\text { Цвет } \\
\text { Colour }\end{array}$ \\
\hline $\begin{array}{l}\text { Готовые сырники из творога имеют } \\
\text { форму кружочков, диаметром 50- } \\
60 \text { мм, высотой 10-15 см массой } 30- \\
40 \text { г., с вкраплением творога и едва } \\
\text { видимых частиц PПС } \\
\text { Ready-made cakes from cottage cheese } \\
\text { are in the form of dots, dia-meter 50- } \\
60 \mathrm{~mm} \text {, a height of } 10-15 \mathrm{~cm} \text {, the weight } \\
\text { of } 30-40 \text { g, interspersed with cottage } \\
\text { cheese and barely visible particles PFS }\end{array}$ & $\begin{array}{l}\text { Мягкая, нежная, неоднородная } \\
\text { по всей массе, в меру плотная, } \\
\text { допускается наличие ощути- } \\
\text { мых частиц творога и мелких } \\
\text { вкраплений РПС } \\
\text { Soft, gentle, non-uniform through- } \\
\text { out the mass, moderately dense, tol- } \\
\text { erance of tangible curd particles } \\
\text { and small inclusions PFS }\end{array}$ & $\begin{array}{l}\text { Чистый, творожный, } \\
\text { без посторонних привку- } \\
\text { сов и запахов, в меру слад- } \\
\text { кий, со слабым, приятным } \\
\text { и привкусом ощущением } \\
\text { PПС } \\
\text { Clean, cottage cheese, with- } \\
\text { out foreign tastes and odors, } \\
\text { moderately sweet, with a } \\
\text { mild, pleasant taste and sensa- } \\
\text { tion of PFS }\end{array}$ & $\begin{array}{l}\text { На изломе молоч- } \\
\text { ный, с желтоватым } \\
\text { оттенком, белыми } \\
\text { вкраплениями тво- } \\
\text { рога и РПС } \\
\text { At the turn of the } \\
\text { milk, with a yellow- } \\
\text { ish tint, white } \\
\text { patches of cottage } \\
\text { cheese and PFS }\end{array}$ \\
\hline
\end{tabular}

Таблица 3

Физико-химические показатели сырников

Table 3

Cheese cakes physical and chemical indices

\begin{tabular}{|c|c|c|c|c|c|c|}
\hline $\begin{array}{c}\text { Наименование полуфабрикатов } \\
\text { на основе творога } \\
\text { Name of semi-finished products based } \\
\text { on cottage cheese }\end{array}$ & $\begin{array}{l}\text { Кислот- } \\
\text { ность, }{ }^{\circ} \text {, } \\
\text { не более } \\
\text { Acidity, } \\
{ }^{\circ} \mathrm{T} \text { max }\end{array}$ & $\begin{array}{c}\text { Массовая } \\
\text { доля } \\
\text { жира, \%, } \\
\text { не менее } \\
\text { Fat } \\
\text { content,\%, } \\
\text { min }\end{array}$ & $\begin{array}{c}\text { Массо- } \\
\text { вая доля } \\
\text { влаги, \% } \\
\\
\text { Moisture } \\
\text { content, } \\
\%\end{array}$ & $\begin{array}{l}\text { Сaxa- } \\
\text { розы, \% }\end{array}$ & $\begin{array}{c}\text { Соли, } \\
\text { не бо- } \\
\text { лее } \\
\\
\text { Salts, } \\
\text { max }\end{array}$ & $\begin{array}{c}\text { Tемпера- } \\
\text { тура при } \\
\text { выпуске, }{ }^{\circ} \mathrm{C} \\
\\
\text { Temperature } \\
\text { at output, }{ }^{\circ} \mathrm{C}\end{array}$ \\
\hline $\begin{array}{l}\text { Тесто для сырников м. д. ж. 13,5\% } \\
\text { Dough for cheesecakes f. m. f. 13,5\% }\end{array}$ & 190 & 13,5 & 54,0 & 8,0 & 0,5 & 8 \\
\hline $\begin{array}{l}\text { Tесто для сырников м. д. ж. 7\% } \\
\text { Dough for cheesecakes f. m. f. 7\% }\end{array}$ & 200 & 7,0 & 60,0 & 8,0 & 0,5 & 8 \\
\hline $\begin{array}{l}\text { Тесто для сырников нежирных } \\
\text { Dough for low-fat cheesecakes }\end{array}$ & 220 & - & 66,0 & 8,0 & 0,5 & 8 \\
\hline $\begin{array}{l}\text { Тесто для сырников м. д. ж. 15\% } \\
\text { Dough for cheesecakes f. m. f. 15\% }\end{array}$ & 200 & 15,0 & 59,0 & - & 1,0 & 8 \\
\hline $\begin{array}{l}\text { Тесто для сырников м. д. ж. 7,5\% } \\
\text { Dough for cheesecakes f. m. f. 7,5\% }\end{array}$ & 220 & 7,5 & 66,0 & - & 1,0 & 8 \\
\hline $\begin{array}{l}\text { Тесто для сырников нежирных } \\
\text { Dough for low-fat cheesecakes }\end{array}$ & 240 & - & 72,0 & - & 1,0 & 8 \\
\hline
\end{tabular}


Для определения КМАФАнМ были взяты образцы: 1 - сырники (контроль), 2 - сырники с РПС. Микробиологические исследования анализируемых быстрозамороженных полуфабрикатов определяли на протяжении 90 суток.

Состав микрофлоры сырников, выработанных по традиционной рецептуре и с добавлением РПС представлены в таблицах 4-5.

Таблица 4 Состав микрофлоры полуфабрикатов, приготовленных по традиционной рецептуре, на 90 сут хранения

Table 4 Microflora of the semi-finished products composition, prepared according to traditional recipes, with 90 days storage

\begin{tabular}{|c|c|c|}
\hline $\begin{array}{c}\text { Продукт } \\
\text { Product }\end{array}$ & \multicolumn{2}{|c|}{$\begin{array}{c}\text { Сырники } \\
\text { Cheеsecakes }\end{array}$} \\
\hline $\begin{array}{c}\text { Разведение } \\
\text { Dilution }\end{array}$ & $1: 10$ & $1: 100$ \\
\hline $\begin{array}{c}\text { Обнаруженный тип: } \\
\text { Discovered Туре: } \\
\text { маленькие колонии / } \\
\text { small colonies } \\
\text { большие колонии / } \\
\text { large соlonies }\end{array}$ & $6,7 \cdot 10^{3}$ & $7,0 \cdot 10^{3}$ \\
\hline $\begin{array}{c}\text { Общее число / } \\
\text { Тоtal пumber }\end{array}$ & $6,2 \cdot 10^{3}$ & $1,8 \cdot 10^{3}$ \\
\hline $\begin{array}{c}\text { Среднее значение / } \\
\text { Аverage value }\end{array}$ & \multicolumn{2}{|c|}{$6,85 \cdot 10^{3}$} \\
\hline
\end{tabular}

На основе проведённых исследований с учётом нормируемых органолептических, физико-химических свойств и микробиологических показателей полуфабрикатов на основе творога была разработана многоуровневая структура, характеризующая качественные показатели (рисунок 2). Где $\mathrm{P}_{0}$ - комплексный показатель, который характеризуется единичными показателями: $\mathrm{P}_{1}$ - пищевая ценность, $\mathrm{P}_{2}$ - органолептические показатели, $\mathrm{P}_{3}$ - физико-химические показатели, $\mathrm{P}_{4}-$ микробиологические показатели, $\mathrm{P}_{5}-$ условия хранения.

Пищевая ценность $\left(\mathrm{P}_{1}\right)$ оценивается на основании химического состава, а именно массовой доли жиров, белков, углеводов, минеральных веществ, витаминов. Органолептические показатели $\mathrm{P}_{2}-$ внешний вид, консистенция, вкус, запах, цвет. Физико-химические $\mathrm{P}_{3}$ - массовая доля белков, жиров и углеводов. Также необходима оценка показателей, оказывающих влияние на кислотность, активность
Из полученных данных видно, что творожные полуфабрикаты с РПС имеют меньшую обсеменённость на 11,7\%. Анализируя полученные данные, можно сделать вывод о соответствии физико-химических, органолептических и микробиологических показателей разработанных продуктов установленным нормам на творожные полуфабрикаты [3].

Таблица 5

Состав микрофлоры полуфабрикатов, приготовленных с добавлением РПС, на 90 сут хранения

Table 5

Microflora of the semi-finished products composition, prepared with the addition of RPS, with 90 days storage

\begin{tabular}{|c|c|c|}
\hline $\begin{array}{c}\text { Продукт } \\
\text { Product }\end{array}$ & \multicolumn{2}{|c|}{$\begin{array}{c}\text { Сырники с добавкой } \\
\text { Cheesecakes with the addi- } \\
\text { tive }\end{array}$} \\
\hline $\begin{array}{c}\text { Разведение } \\
\text { Dilution }\end{array}$ & $1: 10$ & $1: 100$ \\
\hline $\begin{array}{c}\text { Обнаруженный тип: } \\
\text { Discovered Туре: } \\
\text { маленькие колонии / } \\
\text { small colonies } \\
\text { большие колонии / } \\
\text { large colonies }\end{array}$ & $5,9 \cdot 10^{3}$ & $7,0 \cdot 10^{3}$ \\
\hline $\begin{array}{c}\text { Общее число / } \\
\text { Тоtal пumber }\end{array}$ & $5,9 \cdot 10^{3}$ & $1,1 \cdot 10^{3}$ \\
\hline $\begin{array}{c}\text { Среднее значение / } \\
\text { Аverage value }\end{array}$ & \multicolumn{2}{|c|}{$6,0 \cdot 10^{3}$} \\
\hline
\end{tabular}

воды, массовую долю влаги и микробиологические показатели $\left(\mathrm{P}_{4}\right)$ и оценка режимов хранения и сроков годности $\left(\mathrm{P}_{5}\right)$.

Блок-схема производства полуфабрикатов основе творога с учётом вышеперечисленных показателей приведена на рисунке 2 . Результаты анализа риска и перечень учитываемых опасных факторов при производстве полуфабрикатов на основе творога с учётом вышеперечисленных показателей представлены в таблице 6. Для рисков, которые определены как значимые, на каждом технологическом этапе оценка продолжается с использованием алгоритма действия с целью определения и исправления возникших рисков (рисунок 3 ). 
Becmнuк BTYYHTI/Proceedings of VSUET, № 2, 2016

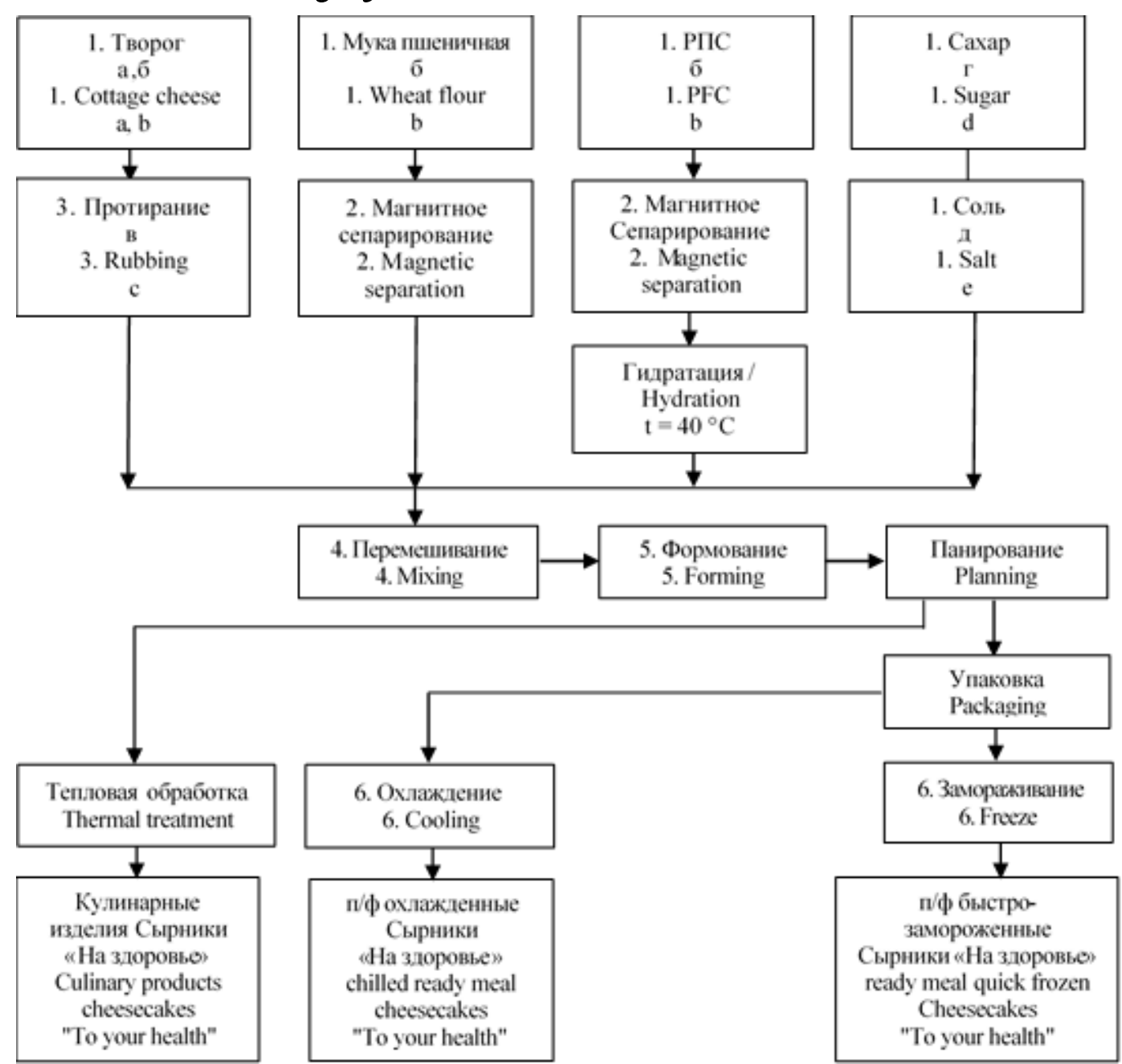

Рисунок 2. Блок-схема производства полуфабрикатов основе творога: а - физико-химический контроль; б - микробиологический контроль; в - органолептический контроль

Figure 2. A block diagram of the production of Semifinished based on of cottage cheese a - physical and chemical control; b - microbiological control; c - organoleptic control

Таблица 6

Критические контрольные точки производства полуфабрикатов на творожной основе

Table 6.

Critical control points in the semi-finished products based on cottage cheese production

\begin{tabular}{|c|c|c|}
\hline $\begin{array}{l}\text { KTT } / \\
\text { CCP }\end{array}$ & $\begin{array}{c}\text { Наименова- } \\
\text { ние } \\
\text { операции / } \\
\text { The name of } \\
\text { the operation }\end{array}$ & $\begin{array}{c}\text { Наименование контрольных параметров / } \\
\text { The name benchmarks }\end{array}$ \\
\hline \multirow[t]{3}{*}{$\begin{array}{l}\text { KTT } 1 / \\
\text { CСР } 1\end{array}$} & $\begin{array}{l}\text { Операция } \\
\text { 1, 2, 3, 4, 5: } \\
\text { a, б } \\
\text { Operation } \\
\text { 1, 2, 3, 4, 5: } \\
\text { a, b }\end{array}$ & $\begin{array}{l}\text { Влажность, зольность, крупность помола; количество и качество сырой клейковины; содер- } \\
\text { жание металомагнитных примесей; заражённость и загрязнённость вредителями хлебных за- } \\
\text { пасов; допустимый уровень токсичных элементов (свинец, кадмий, мышьяк, ртуть, медь, } \\
\text { цинк), микотоксинов (афлатоксин В1, зеараленон и др.), радионуклидов и пестицидов / } \\
\text { Moisture, ash content, fineness of grinding; the quantity and quality of crude gluten; metalomagnit- } \\
\text { nyh impurities content; and pollution of the infestation by pests of grain stocks; permissible level of } \\
\text { toxic elements (lead, cadmium, arsenic, mercury, copper, zinc), mycotoxins (aflatoxin B1, zeara- } \\
\text { lenone, etc..), radionuclides and pesticides }\end{array}$ \\
\hline & $\begin{array}{l}\text { B / } \\
\text { C }\end{array}$ & $\begin{array}{l}\text { Массовая доля жира, белка и влаги; кислотность; количество молочнокислых микроорганизмов / } \\
\text { Mass fraction of fat, protein, and moisture; acidity; the amount of lactic acid microorganisms }\end{array}$ \\
\hline & $\begin{array}{l}\Gamma / \\
\mathrm{d}\end{array}$ & $\begin{array}{l}\text { Количество мезофильных аэробных и факультативно анаэробных микроорганизмов, } \\
\text { КОЕ в } 1 \text { г; плесневые грибы; дрожжи; бактерии группы кишечных палочек; патогенные мик- } \\
\text { роорганизмы; содержание тяжёлых металлов и мышьяка; содержание пестицидов / }\end{array}$ \\
\hline
\end{tabular}




\begin{tabular}{|c|c|c|}
\hline & & $\begin{array}{l}\text { Number mesophilic aerobic and facultative anaerobic bacteria, CFU in } 1 \mathrm{~g} \text {; molds; yeast; coliform } \\
\text { bacteria; pathogens; the content of heavy metals and arsenic; pesticide content }\end{array}$ \\
\hline & $\begin{array}{l}\text { д / } \\
\mathrm{e}\end{array}$ & 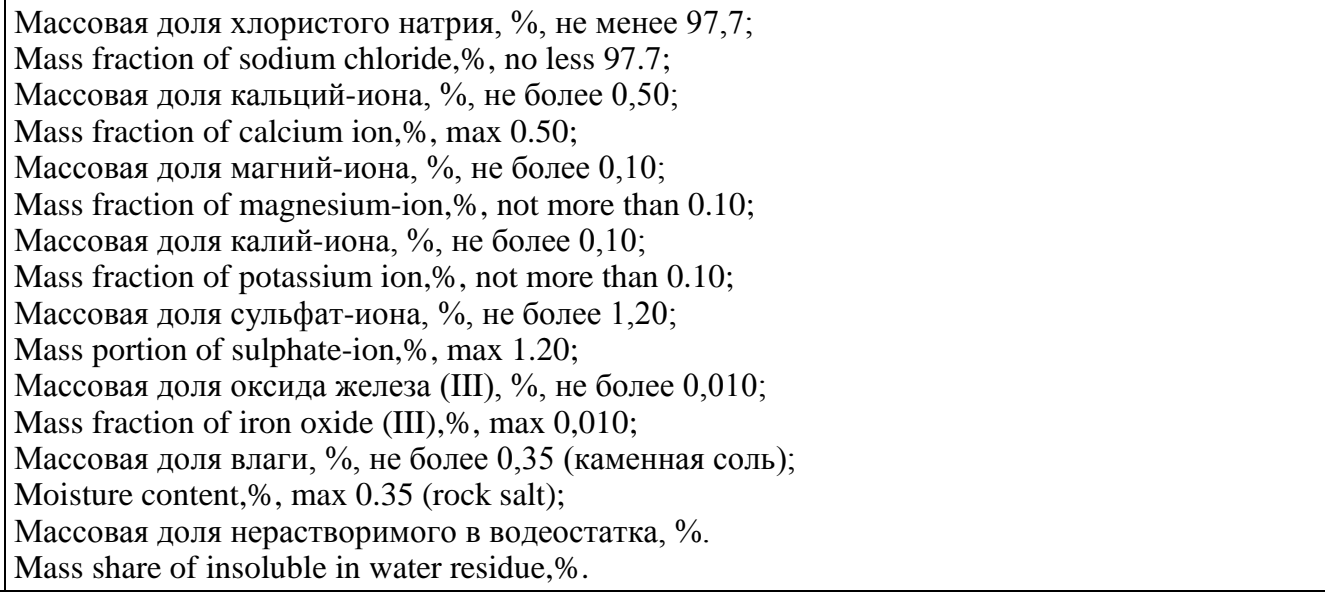 \\
\hline $\begin{array}{l}\text { KTT } 2 / \\
\text { CCP } 2\end{array}$ & $\begin{array}{l}\text { Операция } 5 \text { / } \\
\text { Step } 5\end{array}$ & $\begin{array}{l}\text { БГКП, дрожжи, плесневые грибы, патогенные микроорганизмы, Staphylococcusaureus; мac- } \\
\text { совая доля влаги, жира; титруемая кислотность / } \\
\text { Coliform bacteria, yeast, fungi, pathogens, Staphylococcusaureus; the mass fraction of moisture, fat; } \\
\text { titratable acidity }\end{array}$ \\
\hline $\begin{array}{l}\text { KTT } 3 / \\
\text { CCP } 3\end{array}$ & $\begin{array}{l}\text { Операция } 6 \text { / } \\
\text { Step } 6\end{array}$ & $\begin{array}{l}\text { Температура заморозки, время процесса / } \\
\text { Freezing temperature, process time }\end{array}$ \\
\hline $\begin{array}{l}\text { KTT } 4 / \\
\text { CCP } 4\end{array}$ & $\begin{array}{l}\text { Операция } 7 \text { / } \\
\text { Step } 7\end{array}$ & $\begin{array}{l}\text { Массовая доля влаги, жира; титруемая кислотность; БГКП, дрожжи, плесневые грибы, пато- } \\
\text { генные микроорганизмы, Staphylococcusaureus / } \\
\text { Mass fraction of moisture, fat; titratable acidity; Coliform bacteria, yeast, fungi, pathogenic micro- } \\
\text { organisms, Staphylococcusaureus }\end{array}$ \\
\hline
\end{tabular}

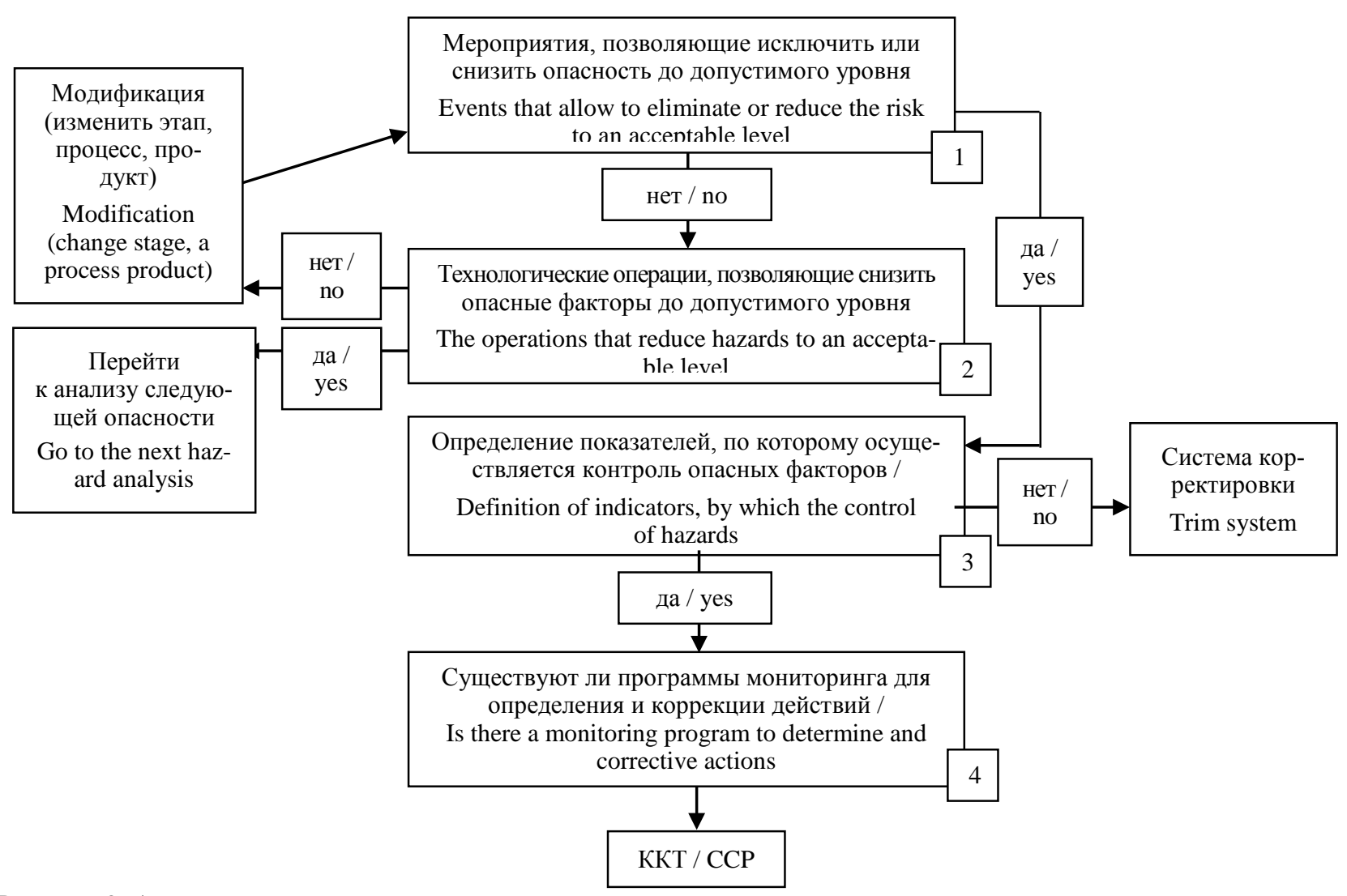

Рисунок 3. Алгоритм действия по определению и снижению рисков

Figure 3. Algorithm of actions to identify and reduce risks

Разработанный алгоритм мониторинга критических контрольных точек по комплексным и

единичным показателям позволит повысить качество и безопасность оценки новых пищевых продуктов. 


\section{ЛИТЕРАТУРА}

1 Замятина О. В. Принципы ХАССП. Безопасность продуктов питания и медицинского оборудования: пер. с англ. М.: РИА «Стандарты и качество», 2006. 232 с.

2 Глаголева Л. Э. , Родионова Н. С. , Корнеева О. С., Шуваева Г. П. Разработка, контроль качества и оценка безопасности энтеросорбирующих биосистем на основе растительных комплексов. Воронеж: ЦНТИ, 2011. 136 с.

3 ТУ «Полуфабрикаты и кулинарные изделия из творога», г. Мичуринск. URL : http://michurinsk.satom.ru/p / 2615337-tu-polufabrikaty-i-kulinarnye-izdeliya-iz-tvoroga. (дата обращения 07.11.2014).

\section{СВЕДЕНИЯ ОБ АВТОРАХ}

Людмила Э. Глаголева д.т.н., профессор, заведующая кафедрой, кафедра туризма и гостиничного дела, Воронеж. гос. ун-т инж. технол., пр. Революции, 19, г. Воронеж, 394036, Россия

Ирина В. Коротких кафедра туризма и гостиничного дела, Воронеж. гос. ун-т инж. технол., пр. Революции, 19, г. Воронеж, 394036, Россия, irina_korotkikh89@mail.ru

\section{КРИТЕРИЙ АВТОРСТВА}

Людмила Э. Глаголева предложил методику проведения эксперимента, консультация в ходе исследования Ирина В. Коротких написал рукопись, корректировал её до подачи в редакцию и несёт ответственность за плагиат

\section{КОНФЛИКТ ИНТЕРЕСОВ}

Авторы заявляют об отсутствии конфликта интересов.

ПОСТУПИЛА 21.03.2016

ПРИНЯТА В ПЕЧАТЬ 18.04.2016

\section{REFERENCES}

1 Zamyatina O.V. Printsipy KhASSP. Bezopasnost' produktov pitaniya i meditsinskogo oborudovaniya [Principles of HACCP. Safety of food and medical-ray equipment: lane. from English] Moscow, RIA "Standarty i kachestvo", 2006. 232 p. (in Russian).

2 Glagoleva L.E., Rodionova N.S., Korneeva O.S., Shuvaeva G.P. Razrabotka, kontrol' kachestva i otsenka bezopasnosti enterosorbiruyushchikh biosistem na osnove rastitel'nykh kompleksov [Development, quality control and safety evaluation enterosorbiruyuschee biosystems based on plant complexes] Voronezh, TsNTI, 2011. 136 p. (in Russian).

3 TU "Polufabrikaty i kulinarnye izdeliya iz tvoroga" [TC "Semi-finished products and culinary products from curd"] Available at: http://michurinsk. satom.ru/p / 2615337 tu-polufabrikaty-i-kulinarnyeizdeliya-iz-tvoroga. (accessed 11/07/2014). (in Russian).

\section{INFORMATION ABOUT AUTHORS}

Lyudmila E. Glagoleva Dc. sci., professor, head of the department, department of tourism and hospitality management, Voronezh state university of engineering technologies, Revolution Av., 19, Voronezh, 394036, Russia

Irina V. Korotkikh department of tourism and hospitality management, Voronezh state university of engineering technologies, Revolution Av., 19, Voronezh, 394036, Russia

\section{CONTRIBUTION}

Lyudmila E. Glagoleva proposed a scheme of the experiment, consultation during the study

Irina V. Korotkikh wrote the manuscript, correct it before filing in editing and is responsible for plagiarism

\section{CONFLICT OF INTEREST}

The authors declare no conflict of interest.

RECEIVED 3.21.2016

ACCEPTED 4.18.2016 